\title{
Employee-related disclosures in corporate annual reports and the King II Report recommendations
}

\section{G Faure}

\section{Department of Financial Management University of Pretoria}

CJ de Villiers

Department of Financial

Management University of Pretoria

\begin{abstract}
The recommendations of the King II Report on corporate governance regarding employee-related disclosures by listed companies were identified. The annual reports of the Top 100 industrial companies as well as of the mining companies listed on the Johannesburg Securities Exchange were furthermore analysed to establish the percentage of companies that comply with the King II recommendations. It transpired that few of them comply fully with these recommendations.
\end{abstract}

Key words

Employee reporting

Corporate governance

\section{Introduction, problem statement and outline of the paper}

The need for good corporate governance has been the focus of steadily increasing attention over the past few years (Murray, Sinclair, Power and Gray 2001; Deakin, Hobbs, Konzelmann and Wilkinson 2002). The importance of this issue in South Africa was underlined by the establishment of the King Committee on Corporate Governance in 1992. The King Report on Corporate Governance (known as the King Report) was published in November 1994.

The 1994 King Report was followed by the King II Report of 2002, which recommends, among other things, that companies should communicate relevant information to all the stakeholders of the company and not only to shareholders (King Committee 2002). Arguably, the largest stakeholder group identified by the King II Report, and in the context of upliftment certainly the most important, is constituted by employees (McCall 2001; Riley 2002). 
South Africa is in the unique situation of having a fairly young democracy, one that finds itself in the midst of a transformation process where much emphasis is placed on the empowerment, upliftment and equality of all citizens. Increased pressure is also being placed on large companies to contribute to this process in a fair and equitable manner. In this regard transparency becomes of the utmost importance and is best achieved when sufficient, appropriate information is disclosed (Keegan and Phillips 2001).

The aims of this paper are

to highlight important information that the King II Report has recommended should be disclosed with regard to the employees as a group of stakeholders, and

$\square$ to review the extent to which these recommended disclosures are in actual fact disclosed by companies.

A content analysis was conducted in respect of the disclosure contained in the annual reports of the Top 100 industrial companies as well as the mining companies listed on the Johannesburg Securities Exchange (JSE). The reason for focusing on the annual report is that this is the only compulsory document that all companies need to publish that contains the relevant information. In certain cases some of the companies publish additional documents stating their contribution towards their employees, but as this is neither mandatory nor general practice it was decided to use the annual reports and thus ensure comparability. The use of only the annual report is supported by a study done by Zeghal and Ahmed (1990), where the initial intention was to make use of all the communications by an organisation to determine the extent of its social and environmental reporting. It was, however, impossible to ensure the identification of all such communications. As a result it was concluded that it was better to focus on the annual report only.

The various sections of this article are organised as follows: Section 1 serves as an introduction, and states the aims of the entire article. Section 2 describes the background to employee reporting and the role of corporate governance. The method that was used to obtain data serving as a basis for this study is described in Section 3. Section 4 contains the results of the study, and is followed by Section 5 in which a conclusion is reached.

\section{Background}

The original King Report went beyond the financial and regulatory aspects of corporate governance and emphasised an integrated approach towards good governance, taking cognisance of the fundamental principles of good financial, social, ethical and environmental practice in the interest of a wide range of stakeholders. 
Subsequent to the publication of the original King Report, the King Committee considered it appropriate to revisit their initial document, and "to review and clarify the earlier proposals in the King Report 1994 for an 'inclusive approach' for the sustainable success of companies" (King II Report). "The "inclusive approach' recognises that stakeholders such as the community in which the company operates, its customers, its employees and its suppliers need to be considered when developing the strategy of a company" (King II Report). The King II Report, published in March 2002, is based on the concept of "triplebottom-line" reporting, which encompasses reporting on an entity's economic, environmental and social performance. According to the Executive Summary of AA1000 Standard (1999), social performance is "the direct and indirect impact of an organisation's activities on stakeholders", while stakeholders are defined as follows: "These [the stakeholders] may include, but are not limited to: owners, trustees, employees etc." Therefore social performance includes employee issues.

The new Code of Corporate Governance for South Africa (King II Report) was developed, and this guideline will be applicable to, among others, listed companies with financial years commencing on or after 1 March 2002.

The Basic Conditions of Employment Act was promulgated in 1997, and all employers in South Africa must comply with the provisions of this Act in their dealings with their employees (Basic Conditions of Employment Act, 1997 (Act No. 75 of 1997)). Thus, the responsibility of an employer towards an employee is more than merely a social responsibility; it also comprises a legal responsibility.

In their book, Living Corporate Citizenship, Mcintosh, Thomas, Leipziger and Coleman (2002) give an indication of the "Global Eight" initiatives that are the driving force behind the principles of and reporting on corporate citizenship. Among the eight is that pertaining to the "Global Sullivan Principles", which constitute the forerunner of the King Report in South Africa (Sullivan 1984). As the King II Report was based on the principles of the Sullivan Code, it is clear that the King II Report is in line with international standards. Many South African companies list on foreign exchanges and it thus is important to ensure that the standard of reporting in South Africa is at a level that is on par with international standards.

\section{Method}

The following method was employed to conduct the analysis: A summary was made of all the recommended forms of disclosure in the King II Report pertaining to employees. A checklist was developed according to these recommendations and this was used to analyse the annual report of the companies included in the

Meditari Accountancy Research Vol. 12 No. 12004 : 61-75 
study. The results indicate the percentage of companies that report each of the types of employee information recommended by the King II Report.

\subsection{Checklist}

The checklist consists of a number of questions that assess the reporting by companies of employee-related matters. The checklist was applied to annual reports of companies for the period from 1999 to 2001. Two sets of companies were identified. The first set of companies comprises the Financial Mail Top 100 Industrial Companies. However, this listing was only available until the end of 1999, after which the Top 100 Industrial Companies as rated by McGregor BFA was used. The listing according to McGregor BFA is based on total assets, the same basis that was used by the Financial Mail. It was therefore concluded that the information as previously supplied by the Financial Mail is comparable to the information supplied by McGregor BFA. The second set of companies includes all the mining companies listed on the JSE. The King II Report is applicable to all companies listed on the JSE and the annual reports of listed companies are readily available. This facilitated the research and is the major reason for having chosen the abovementioned two groups of companies.

The researchers were curious about the history of reporting that emerged from some of the questions on the checklist. Hence the 1997 and 1998 annual reports were also analysed to obtain a more complete picture. Since a number of questions still provided inconclusive results, it was decided to go back to 1994 and review corporate employee reporting practices over a longer period in order to gain a more complete picture of the historical progression.

\section{Results of the study}

\subsection{Recommendations identified in the King II Report regarding employee reporting}

The recommendations pertaining to the reporting of employee-related information that were identified in the King II Report are summarised in the table below. The question numbers referred to in each case relate to the checklist that the researchers used to assess companies' reporting on the matter concerned. 
Table 1 Summary of recommendations and corresponding questions in checklist

\section{Sustainability Reporting}

- Every company should report at least annually on the nature and extent of its (King II Report, pp. 35, par. 5.1.1)

- social and transformation issues,

- ethical issues,

- safety and health issues.

- Stakeholders' reporting requires an integrated approach. Companies should categorise issues into the following levels of reporting (King II Report, pp. 35, par. 5.1.2):

- First level: Disclosure relating to acceptance and adoption of business principles and/or codes of practice.

- Second level: Address the implementation of practices in keeping with accepted principles involving a review of steps taken to encourage adherence to these principles evidenced by board directors, designated policies and communiqués, supported by appropriate non-financial accounting mechanisms.

- Third level: Investigation and demonstration of changes and benefits that have resulted from the adoption and implementation of stated business principles and/or codes of practice.

- Matters requiring specific consideration should include the following (King II Report, pp. 36, par. 5.1.4):

- Description of practices reflecting a committed effort at reducing workplace accidents, fatalities as well as occupational health and safety incidents against stated measurement targets and objectives, and a suitable explanation where appropriate.

- The above would cover the nature and extent of the strategy, as well as plans and policies adopted to address and manage the potential impact of HIV/AIDS on the company's activities.

- Policies that define social investment prioritisation and spending, as well as the extent of initiatives to support black economic empowerment - in particular, procurement practices and investment

Addressed by Question Number

Questions 1 \& 10

Question 9

Question 7

Question 9

Question 5

Question 5

Question 7

Question 8

Questions 2 - 4, 6, $11 \& 12$ strategies. 
1 Sustainability Reporting - continued

- Disclosure of human capital development in areas such as the number of staff. This should also address issues that create the conditions and opportunities for previously disadvantaged individuals to have an equal opportunity to reach executive levels in the company and to realise their full potential. It should include progress made in this regard, and mechanisms to positively reinforce the richness of diversity and the added value and contribution from this diversity.

2 Organisational Integrity/Code of Ethics

- Disclosure should be made of adherence to the company's code of ethics (King II Report, pp. 38, par. 5.2.3).

Addressed by Question Number

Questions 2 - 4, 6,

$11 \& 12$

Question 5

\subsection{Do companies disclose the information recommended by the King II Report?}

The disclosure recommendations in Table 1 can be divided into three categories, namely "Disclosure on policies regarding employees", "Health and safetyrelated disclosure", and "Sustainability disclosure". The results of the study are therefore summarised below under these category headings. 
Table 2 Disclosure as identified by means of Questions 1 to 12

\begin{tabular}{|c|c|c|c|c|c|c|c|c|}
\hline \multicolumn{9}{|c|}{$\begin{array}{l}\text { Question } 1 \\
\text { Does the corporate policy/mission statement mention a policy/mission regarding } \\
\text { social/community issues? }\end{array}$} \\
\hline & & & & & 1999 & \multicolumn{2}{|c|}{2000} & 2001 \\
\hline \multicolumn{5}{|l|}{ Top 100 Industrials } & $61 \%$ & \multicolumn{2}{|c|}{$25 \%$} & $18 \%$ \\
\hline \multicolumn{5}{|l|}{ Mining companies } & $21 \%$ & \multicolumn{2}{|c|}{$24 \%$} & $18 \%$ \\
\hline \multicolumn{9}{|c|}{$\begin{array}{l}\text { Question } 2 \\
\text { Is the company's employment policy disclosed? }\end{array}$} \\
\hline & 1994 & 1995 & 1996 & 1997 & 1998 & 1999 & 2000 & 2001 \\
\hline Top 100 Industrials & $82 \%$ & $72 \%$ & $69 \%$ & $89 \%$ & $85 \%$ & $89 \%$ & $77 \%$ & $77 \%$ \\
\hline Mining companies & $38 \%$ & $41 \%$ & $43 \%$ & $41 \%$ & $36 \%$ & $38 \%$ & $54 \%$ & $41 \%$ \\
\hline
\end{tabular}

\section{Question 3}

Does the company disclose whether it subscribes to a code of conduct regarding policies?

\begin{tabular}{|l|c|c|c|c|c|c|c|c|}
\hline & 1994 & 1995 & 1996 & 1997 & 1998 & 1999 & 2000 & 2001 \\
\hline Top 100 Industrials & $2 \%$ & $11 \%$ & $10 \%$ & $87 \%$ & $95 \%$ & $95 \%$ & $94 \%$ & $95 \%$ \\
\hline Mining companies & $2 \%$ & $3 \%$ & $3 \%$ & $3 \%$ & $78 \%$ & $83 \%$ & $92 \%$ & $91 \%$ \\
\hline
\end{tabular}

Question 4

Does the company disclose any information regarding affirmative action?

\begin{tabular}{|l|l|l|l|l|l|l|}
\hline & 1996 & 1997 & 1998 & 1999 & 2000 & 2001 \\
\hline Top 100 Industrials & $59 \%$ & $84 \%$ & $39 \%$ & $36 \%$ & $82 \%$ & $86 \%$ \\
\hline Mining companies & $28 \%$ & $33 \%$ & $71 \%$ & $54 \%$ & $50 \%$ & $45 \%$ \\
\hline
\end{tabular}

\section{Question 5}

Does the annual report mention information regarding audits for social/ community/ethical activities?

\begin{tabular}{|l|c|c|c|}
\hline & 1999 & 2000 & 2001 \\
\hline Top 100 Industrials & $11 \%$ & $4 \%$ & $1 \%$ \\
\hline Mining companies & $15 \%$ & $2 \%$ & $2 \%$ \\
\hline
\end{tabular}

continued 


\begin{tabular}{|c|c|c|c|c|c|c|c|c|}
\hline \multicolumn{9}{|c|}{ Category 1 - Disclosure on policies regarding employees } \\
\hline \multicolumn{9}{|c|}{$\begin{array}{l}\text { Question } 6 \\
\text { Does the corporate policy/mission statement mention a policy/mission regarding the } \\
\text { employees? }\end{array}$} \\
\hline & 1994 & 1995 & 1996 & 1997 & 1998 & 1999 & 2000 & 2001 \\
\hline Top 100 Industrials & $51 \%$ & $43 \%$ & $41 \%$ & $52 \%$ & $52 \%$ & $86 \%$ & $76 \%$ & $36 \%$ \\
\hline Mining companies & $13 \%$ & $14 \%$ & $17 \%$ & $25 \%$ & $29 \%$ & $27 \%$ & $56 \%$ & $27 \%$ \\
\hline \multicolumn{9}{|c|}{ Category 2 - Health and safety-related disclosure } \\
\hline \multicolumn{9}{|c|}{$\begin{array}{l}\text { Question } 7 \\
\text { Does the company disclose any information regarding health and safety issues? }\end{array}$} \\
\hline & 1994 & 1995 & 1996 & 1997 & 1998 & 1999 & 2000 & 2001 \\
\hline Top 100 Industrials & $44 \%$ & $47 \%$ & $36 \%$ & $33 \%$ & $44 \%$ & $36 \%$ & $40 \%$ & $48 \%$ \\
\hline Mining companies & $38 \%$ & $45 \%$ & $43 \%$ & $54 \%$ & $57 \%$ & $60 \%$ & $66 \%$ & $68 \%$ \\
\hline
\end{tabular}

Question 8

Does the annual report disclose any information on AIDS?

\begin{tabular}{|l|c|c|c|}
\hline & 1999 & 2000 & 2001 \\
\hline Top 100 Industrials & $15 \%$ & $16 \%$ & $31 \%$ \\
\hline Mining companies & $31 \%$ & $32 \%$ & $45 \%$ \\
\hline Category 3 - Sustainability disclosure
\end{tabular}

Question 9

Does the annual report mention business principles/ethics?

\begin{tabular}{|l|c|c|c|}
\hline & 1999 & 2000 & 2001 \\
\hline Top 100 Industrials & $93 \%$ & $84 \%$ & $79 \%$ \\
\hline Mining companies & $65 \%$ & $56 \%$ & $64 \%$ \\
\hline
\end{tabular}

Question 10

Does the annual report mention sustainability/sustainable development?

\begin{tabular}{|l|l|l|l|l|l|l|}
\hline & 1996 & 1997 & 1998 & 1999 & 2000 & 2001 \\
\hline Top 100 Industrials & $59 \%$ & $84 \%$ & $39 \%$ & $36 \%$ & $82 \%$ & $86 \%$ \\
\hline Mining companies & $28 \%$ & $33 \%$ & $71 \%$ & $54 \%$ & $50 \%$ & $45 \%$ \\
\hline
\end{tabular}

continued 


\begin{tabular}{|c|c|c|c|c|c|c|c|c|}
\hline \multicolumn{9}{|c|}{ Category 3 - Sustainability disclosure } \\
\hline \multicolumn{9}{|c|}{$\begin{array}{l}\text { Question } 11 \\
\text { Does the company disclose information regarding structured training/education of } \\
\text { employees? }\end{array}$} \\
\hline & 1994 & 1995 & 1996 & 1997 & 1998 & 1999 & 2000 & 2001 \\
\hline Top 100 Industrials & $79 \%$ & $70 \%$ & $67 \%$ & $79 \%$ & $84 \%$ & $74 \%$ & $76 \%$ & $74 \%$ \\
\hline Mining companies & $27 \%$ & $36 \%$ & $39 \%$ & $47 \%$ & $44 \%$ & $52 \%$ & $48 \%$ & $50 \%$ \\
\hline \multicolumn{9}{|c|}{$\begin{array}{l}\text { Question } 12 \\
\text { Does the company disclose any information aimed at the upliftment/improvement of } \\
\text { society? }\end{array}$} \\
\hline \multicolumn{3}{|l|}{ Top 100 Industrials } & 1996 & 1997 & 1998 & 1999 & 2000 & 2001 \\
\hline \multicolumn{3}{|l|}{ Housing } & $11 \%$ & $13 \%$ & $6 \%$ & $4 \%$ & $2 \%$ & $2 \%$ \\
\hline \multicolumn{3}{|l|}{ Clinics } & $18 \%$ & $22 \%$ & $17 \%$ & $11 \%$ & $12 \%$ & $15 \%$ \\
\hline \multicolumn{3}{|l|}{ Sport } & $8 \%$ & $14 \%$ & $12 \%$ & $16 \%$ & $14 \%$ & $22 \%$ \\
\hline \multicolumn{3}{|l|}{ Literacy } & $49 \%$ & $55 \%$ & $30 \%$ & $31 \%$ & $36 \%$ & $38 \%$ \\
\hline \multicolumn{3}{|l|}{ New jobs } & $20 \%$ & $36 \%$ & $26 \%$ & $24 \%$ & $18 \%$ & $21 \%$ \\
\hline \multicolumn{3}{|l|}{ Bursaries } & $\mathrm{N} / \mathrm{A}$ & $\mathrm{N} / \mathrm{A}$ & $31 \%$ & $22 \%$ & $15 \%$ & $19 \%$ \\
\hline \multicolumn{3}{|l|}{ Schools } & $\mathrm{N} / \mathrm{A}$ & $\mathrm{N} / \mathrm{A}$ & $29 \%$ & $29 \%$ & $30 \%$ & $32 \%$ \\
\hline \multicolumn{3}{|c|}{ Social/Community issues } & $\mathrm{N} / \mathrm{A}$ & $\mathrm{N} / \mathrm{A}$ & $\mathrm{N} / \mathrm{A}$ & $40 \%$ & $39 \%$ & $59 \%$ \\
\hline \multicolumn{3}{|l|}{ Mining companies } & 1996 & 1997 & 1998 & 1999 & 2000 & 2001 \\
\hline \multicolumn{3}{|l|}{ Housing } & $6 \%$ & $11 \%$ & $4 \%$ & $2 \%$ & $6 \%$ & $5 \%$ \\
\hline \multicolumn{3}{|l|}{ Clinics } & $9 \%$ & $11 \%$ & $11 \%$ & $8 \%$ & $10 \%$ & $14 \%$ \\
\hline \multicolumn{3}{|l|}{ Sport } & $3 \%$ & $5 \%$ & $8 \%$ & $8 \%$ & $6 \%$ & $9 \%$ \\
\hline \multicolumn{3}{|l|}{ Literacy } & $21 \%$ & $29 \%$ & $21 \%$ & $25 \%$ & $22 \%$ & $20 \%$ \\
\hline \multicolumn{3}{|l|}{ New jobs } & $11 \%$ & $13 \%$ & $13 \%$ & $29 \%$ & $14 \%$ & $14 \%$ \\
\hline \multicolumn{3}{|l|}{ Bursaries } & $\mathrm{N} / \mathrm{A}$ & $\mathrm{N} / \mathrm{A}$ & $11 \%$ & $15 \%$ & $10 \%$ & $9 \%$ \\
\hline \multicolumn{3}{|l|}{ Schools } & $\mathrm{N} / \mathrm{A}$ & $\mathrm{N} / \mathrm{A}$ & $19 \%$ & $21 \%$ & $14 \%$ & $16 \%$ \\
\hline \multicolumn{3}{|c|}{ Social/Community issues } & $\mathrm{N} / \mathrm{A}$ & $\mathrm{N} / \mathrm{A}$ & $\mathrm{N} / \mathrm{A}$ & $27 \%$ & $24 \%$ & $27 \%$ \\
\hline
\end{tabular}




\subsection{Comments and discussion}

Disclosure on policies regarding employees (cf. Table 2, Category 1)

\section{Question 1}

A decline in reporting was experienced in the Top 100 industrial companies, which may be as a result of the fact that the first King Report had been issued in 1994, and this report had not stated as clearly the recommended disclosures on social/community issues as did the King II Report. Furthermore, at the time there was an increasing worldwide trend of reporting on environmental, health and safety issues(Gray 2000; Gray, Collison and Bebbington 1998), while disclosure of social information was still unusual. A study conducted in the US in 2001 found that $35 \%$ of the Fortune 250 largest companies published stand-alone environmental, health and safety reports in addition to their financial report, while disclosure of social information was unusual (World Watch March 2001). From the onset, the rate of reporting on social/community issues was not very high as far as the mining companies were concerned, and the level of disclosure remained constant.

\section{Question 2}

The promulgation of the Basic Conditions of Employment Act in 1997 explains the marked increase in disclosure of employment policy for the Top 100 industrial companies during 1997. In comparison, such disclosure by the mining companies consistently remained fairly low over the entire period - perhaps due to the fact that the mineral and energy sector is more heavily regulated as far as employment policies and practices are concerned.

\section{Question 3}

It is clear from the analysis of data for Question 3 that both the Top 100 industrial companies and the mining companies substantially increased the disclosure of their adherence to a code of conduct regarding employment policies after the Basic Conditions of Employment Act of 1997 had been promulgated.

\section{Question 4}

The Top 100 industrial companies' disclosure with regard to affirmative action increased drastically from 1996 to 2001 . This change is perfectly correlated with the political movement and changes that have taken place in South Africa from 1994 when the first democratic elections took place. Even though the extent to which mining companies report on affirmative action increased by $60 \%$ (from $28 \%$ to $45 \%$ ) in the period from 1994 to 2001, only $45 \%$ of the mining companies report on affirmative action at all. A possible reason offered for this phenomenon is the company structure of a mining company, where there are 
normally a large number of blue-collar workers who traditionally tend to be black people, and where only a small proportion of workers are at management level. Therefore, as far as affirmative action is concerned, the mining companies' employment ratios have always been closer to the desired ratios than those of the Top 100 industrial companies.

\section{Question 5}

It is evident that to date the two groups of companies have not placed a lot of emphasis on the "accountability" of their social/community/ethical activities. A possible reason for this is that there is presently no clear guidance on what is expected from a company with respect to its contribution to the community, and there is no defined way in which a company's performance in this regard can be measured. With the implementation of the King II Report this situation will most probably change quite drastically.

\section{Question 6}

The disclosure of a policy/mission regarding employees for the Top 100 industrial companies decreased in real terms between 1994 and 2001, while the disclosure of a policy/mission regarding employees for the mining companies doubled over the same period. There does not appear to be any obvious reason for the shift in disclosure for the two sets of companies, and it is probable that the inequality of reporting between the two sets will be eliminated once the recommendations from the King II Report are incorporated by all the appropriate companies.

Health and safety-related disclosure (cf. Table 2, Category 2)

\section{Question 7}

The disclosure on health and safety for the Top 100 industrial companies remained fairly consistent between 1994 and 2001. However, the disclosure for the mining companies increased steadily over the period of the study, with the most significant increase recorded in 1997. The increase in disclosure can be attributed to the nature of their business and the inherent health and safety risks attached to mining. Furthermore, as discussed in Question 2, the Basic Conditions of Employment Act was promulgated in 1997, which placed further emphasis on the basic rights of employees to be safeguarded against unnecessary health and safety risks.

\section{Question 8}

It is clear from the analysis in Table 2 that the increasing public awareness with regard to the AIDS situation in the country is reflected in a growing trend among companies to consider it their responsibility to report on the matter.

Sustainability disclosure (cf. Table 2, Category 3 )

Meditari Accountancy Research Vol. 12 No. 12004 : 61-75 


\section{Question 9}

While the disclosure of business principles/ethics by both groups of companies remained fairly consistent over the period from 1999 to 2001, the mining companies generally reported to a lesser extent on these matters. This lower level of disclosure by mining companies may perhaps be attributed to the fact that the mining industry is a fairly isolated sector that is not only heavily regulated, but also the focus of many external groups (such as the government). The Top 100 industrial companies, in contrast, span a number of sectors that are not that heavily regulated, and the companies therefore have to disclose their "companyspecific policies".

\section{Question 10}

Although reporting on sustainability by the Top 100 industrial companies increased between 1996 and 2001, a quite marked decline was experienced in 1998 and 1999. The figures in Table 2 show that reporting by the mining companies reached a high in 1998 and generally increased between 1996 and 2001.

\section{Question 11}

At best, only $52 \%$ of the mining companies reported on structured training during the period from 1994 to 2001. This could be expected, as the bulk of their employees were manual labourers who - in most cases - would not require any further training after the initial training, seeing that their job descriptions are fairly specific. The level of reporting on structured training provided by the Top 100 industrial companies was quite high and remained consistent over the eight years covered by the survey.

\section{Question 12}

Both the Top 100 industrial companies and the mining companies increased their awareness, participation and reporting of their involvement in social/ community issues.

\section{Conclusion}

The conclusions below are summarised according to the different categories of reporting that were identified in Section 4. 


\subsection{Disclosure on policies regarding employees (Category 1)}

Almost all of the Top 100 industrial companies (95\%), as well as all the mining companies (91\%), reported that they subscribed to a code of conduct regarding policies. In 2001, 77\% of the Top 100 industrial companies and $41 \%$ of the mining companies disclosed their employment policy. In addition, $86 \%$ of the Top 100 industrial companies reported information regarding affirmative action, while $45 \%$ of the mining companies reported such information in 2001 . The area in which both groups of companies recorded low reporting percentages is with regard to social/community policy or mission (Question 1), where only $18 \%$ of the Top 100 industrial companies and $18 \%$ of the mining companies reported or disclosed the existence of any such policy or mission in 2001.

\subsection{Health and safety-related disclosure (Category 2)}

Disclosure of issues related to health and safety remained fairly consistent for the Top 100 industrial companies over the period 1994 to 2001. In contrast, this appears to have become a focus area for reporting for the mining companies, as the extent of disclosure increased by almost $80 \%$ (from $38 \%$ to $68 \%$ ) over the same period. The annual disclosure for both sets of companies on the topic of AIDS also increased steadily after 1999. However, in view of the present situation in South Africa and the strong focus on the disease, one would envisage that reporting on AIDS will increase dramatically in the near future.

\subsection{Sustainability disclosure (Category 3)}

The extent of current reporting on sustainability as well as business principles and ethics by the Top 100 industrial companies appears to be at an acceptable level. In $200186 \%$ of companies reported on sustainability, with $79 \%$ reporting on business principles and ethics. However, during that same year only $45 \%$ of the mining companies reported on sustainability, and $64 \%$ on business principles and ethics.

It is clear from the above figures that both the Top 100 industrial companies and the mining companies need to pay particular attention to what they report on in their annual reports. They also need to ensure that they report on all the employee-related matters recommended by the King II Report. In order to create an environment of transparency, it is important that companies adhere to the minimum reporting requirements set by the King II Report.

Meditari Accountancy Research Vol. 12 No. 12004 : 61-75 


\section{Bibliography}

Basic Conditions of Employment Act, (No. 75 of 1997) Government Printer, Pretoria.

Deakin, S., Hobbs, R., Konzelmann, S. and Wilkinson, F. 2002. Partnership, ownership and control: The impact of corporate governance on employment relations, Employee Relations, Vol. 24, No. 3, pp.335-352.

Financial information not enough for investors, World Watch, Governance and Corporate Reporting, PricewaterhouseCoopers, March 2001, p. 22-23.

Gray, R. 2000. Current developments and trends in social and environmental auditing, reporting \& attestation: A personal perspective, Selected Discussion Papers as published on CSEAR website. http://www.gla.ac.uk/departments/ accounting/csear (Accessed on 23 June 2003).

Gray, R., Collison, D. and Bebbington, J. 1998. Environmental and social accounting \& reporting, Chapter in: Financial Reporting Today: Current Trends and Emerging Issues. Milton Keynes, England, 1998.

Institute of Social and Ethical Accountability. 1999. Accountability 1000 Framework (AA1000), Exposure Draft. UK:ISEA.

Keegan, M. and Phillips, D. 2001. Corporates raise the standard of the reporting revolution, World Watch, Governance and Corporate Reporting, PricewaterhouseCoopers, March 2001, pp.22-23.

King Committee on Corporate Governance. 2002. King Report on Corporate Governance for South Africa - 2002, (King II Report), March 2002, Institute of Directors.

McCall, J.J. 2001. Employee voice in corporate governance: A defense of strong participation rights, Business Ethics Quarterly, Jan 2001, Vol. 11, No. 1, p. 195.

Mcintosh, M., Thomas, R., Leipziger, D. and Coleman, G. 2002. Living Corporate Citizenship - Strategic Routes to Socially Responsible Business, Financial Times Prentice Hall, UK, 2002.

Murray, A., Sinclair, D., Power, D. and Gray, R. 2001. Do financial markets care about social and environmental disclosure? Further Evidence and Exploration from the $U K$, Selected discussion papers as published on CSEAR website, http://www.gla.ac.uk/departments/accounting/csear (Accessed on 23 June 2003).

Riley, J. 2002. Lessons from Ansett: Locating the employee's voice in corporate enterprise, Alternative Law Journal, June 2002, Vol. 27, No. 3, p.112.

Sullivan, L. 1984. Sullivan global principles for business (Sullivan Code), www.globalsullivanprinciples.org 
Zeghal, D. and Ahmed, S.A. 1990. Comparison of social responsibility information disclosure media used by Canadian firms, Accounting, Auditing and Accountability Journal, Vol. 3, No. 1, pp.38-53. 